\title{
Nest, eggs and nestling description of the Silvery-flanked Antwren Myrmotherula luctuosa (Pelzeln, 1868) in the Atlantic Forest of northeast Brazil
}

\author{
Cleverton da Silva ${ }^{1,5}$, Cristiano Schetini de Azevedo ${ }^{2}$, Juan Ruiz-Esparza ${ }^{3}$ \\ \& Adauto de Souza Ribeiro ${ }^{4}$
}

\footnotetext{
Programa de Pós-Graduação em Desenvolvimento e Meio Ambiente, Universidade Federal de Sergipe, Campus Universitário Prof. José Aloísio de Campos, Av. Marechal Rondon, s/n, 49100-000, São Cristóvão, SE, Brazil.

2 Departamento de Biodiversidade, Evolução e Meio Ambiente, Instituto de Ciências Exatas e Biológicas, Universidade Federal de Ouro Preto, Campus Morro do Cruzeiro, s/n, Bauxita, 35400-000, Ouro Preto, MG, Brazil.

3 Universidade Federal de Sergipe, Campus do Sertão, Rod. Engenheiro Jorge Neto, km 3, Silos, 49680-000, Nossa Senhora da Glória, SE, Brazil. ${ }^{4}$ Departamento de Ecologia, Centro de Ciências Biológicas e da Saúde, Universidade Federal de Sergipe, Campus Universitário Prof. José Aloísio de Campos, Av. Marechal Rondon, s/n, 49100-000, São Cristóvão, SE, Brazil.

5 Corresponding author: silvac.bio@gmail.com
}

Received on 08 March 2019. Accepted on 10 December 2019.

\begin{abstract}
In the present study, we describe the nest, eggs, and nestlings of the Silvery-flanked Antwren, Myrmotherula luctuosa. One nest was found on 08 May 2017 on the edge of one of the forest fragments of the Serra de Itabaiana National Park, in the state of Sergipe, northeast Brazil, and was monitored until 21 May 2017. The nest, presented the following dimensions: external height: $7.6 \mathrm{~cm}$; outside diameter: $21 \times 19 \mathrm{~cm}$; internal diameter: $13.3 \times 11 \mathrm{~cm}$; depth of the oologic chamber: $4.7 \mathrm{~cm}$; and height in relation to the ground: $84 \mathrm{~cm}$. The two eggs found in the nest were white with reddish-brown dots, patches and stripes and weighed 1.7 and $1.5 \mathrm{~g}$. Incubation was performed by both the male and female, as well as feeding of the nestlings. A single egg hatched, giving rise to a $3.9 \mathrm{~cm}, 3.7 \mathrm{~g}$ nestling. According to our estimates, the young fledged with about 11 days. This is the first study to present information about the reproductive biology of the Silvery-flanked Antwren.
\end{abstract}

KEY-WORDS: Itabaiana National Park, parental care, reproduction, Thamnophilidae.

\section{INTRODUCTION}

Most species of the Thamnophilidae family are considered socially monogamous and form permanent breeding pairs who defend their territories with considerable vigor throughout the year (Zimmer \& Isler 2003). Within this family, the genus Myrmotherula is the most numerous. Chaparro-Herrero \& Ruiz-Ovalle (2014) pointed out that information on the reproductive biology of this genus is limited to nest descriptions and parental care in a few species. Of the 20 species within this genus in Brazil, there is enough information about reproduction only for seven species (M. surinamensis, M. pacifica, M. multostriata, $M$. axillaris, $M$. longipennis, $M$. unicolor and $M$. menetriesii); for other six species there is no information about reproduction or, only anecdotal information is available (Zimmer et al. 2019).

Nests are described as a ball of dead leaves with a mean diameter of $8 \mathrm{~cm}$, suspended in forks varying from 2 to $10 \mathrm{~m}$ above the ground; normal clutch size of 2 white eggs with reddish spots; incubation varying from 16 to 19 days and parental care provided by both parents (Zimmer et al. 2019).

The Silvery-flanked Antwren (Myrmotherula lucutosa) inhabits the understory of primary and secondary Atlantic Forest areas from Brazil (Sick 1997, del Hoyo et al. 2019). It presents a marked sexual dimorphism, with males paler than females, presenting a blackish belly and a pale grey flank; females are more olive-tinged grey with an ochraceous belly (Grantsau 2010). It is insectivorous and little is known about its reproduction, only mentioned that its nest is similar in shape, size and materials to that of the White-flanked Antwren M. axillaris (Zimmer \& Isler 2003, del Hoyo et al. 2019). In this way, this study aimed to provide information on the reproductive biology of the Silvery-flanked Antwren, presenting for the first time information about nest, eggs, and parental care.

\section{METHODS}

The study was carried out in May 2017 in the Serra 
de Itabaiana National Park (PARNASI), Sergipe state, northeastern Brazil $\left(10^{\circ} 40^{\prime} \mathrm{S} ; 37^{\circ} 25^{\prime} \mathrm{W}\right)$. PARNASI is formed by a complex of three mountain ranges: Cajueiro, Comprida and Itabaiana. The three mountain ranges together comprise an area of 7966 ha, and the highest point is in the Itabaiana mountain range, $660 \mathrm{~m}$ a.s.l. (Carvalho \& Vilar 2005). The park area is in a transition between the Atlantic Forest and Caatinga Biomes. The climate of the region is tropical with dry summer and moderate wet winter, with temperatures varying between 17 and $23^{\circ} \mathrm{C}$ (Vicente 1999).

Nest monitoring started at the time of its discovery; it was visited at intervals of 3 to 4 days. The nest, eggs and the nestling were described, weighed and measured using a caliper, accurate to $0.01 \mathrm{~mm}$, and a spring scale, accurate to $0.1 \mathrm{~g}$. During critical phases, such as hatching and fledging, the nest was monitored at shorter intervals of 1 to 2 days, always trying to minimize the impacts caused by human presence. The measurements of the nest were obtained on the day of its discovery, to avoid natural deformations due to its use. Nest characteristics measured were: height of the external part of the nest, external and internal diameter, depth of the oological chamber (edge of the nest until the deepest area of its center) and height of the nest in relation to the ground (the latter with the aid of a measuring tape). In the case of the nestling, its developmental stage was described based on its mass $(\mathrm{g})$, size $(\mathrm{cm})$, shape and color of feathers, beak and tarsi, and on the presence of closed or open eyes.

\section{RESULTS}

On 08 May 2017, a nest of M. luctuosa was found on the edge of one of the fragments of Atlantic Forest located in the PARNASI. The nest was found hidden beneath a leaf of Heliconia sp. (Heliconiaceae) and was strongly attached to a horizontal fork of a sapling, $84 \mathrm{~cm}$ above the ground. At that time, the female was incubating two eggs. The nest was a deep cup made up mainly of fragments of dry leaves of different plant species, and the incubatory chamber was lined with a large amount of light brown flexible rootlets. The whole structure was contained within a flimsy basket of black rootlets filaments that also provided attachment to the horizontal fork (Fig. 1). Nest measurements were: height of the external part of the nest $(7.6 \mathrm{~cm})$, external diameter $(21 \times 19 \mathrm{~cm})$, internal diameter $(13.3 \times 11 \mathrm{~cm})$, depth of the oological chamber $(4.7 \mathrm{~cm})$, and height of the nest in relation to the ground $(84 \mathrm{~cm})$.

Eggs were white with reddish-brown dots and stripes on the terminal portion of the rhombus pole (Fig. 1A). On 12 May 2017, it was observed that only one chick had hatched. The mass, diameter and length of the eggs are presented in Table 1.

The nestling registered on 12 May 2017 measured $3.9 \mathrm{~cm}$ and weighed $3.7 \mathrm{~g}$. It had no feathers, had closed eyes, pale skin and tarsi, and yellow-orange beak, labial commissure, tongue and mouth lining (Fig. 1B). On 14 May 2017, there were already open eyes and clear

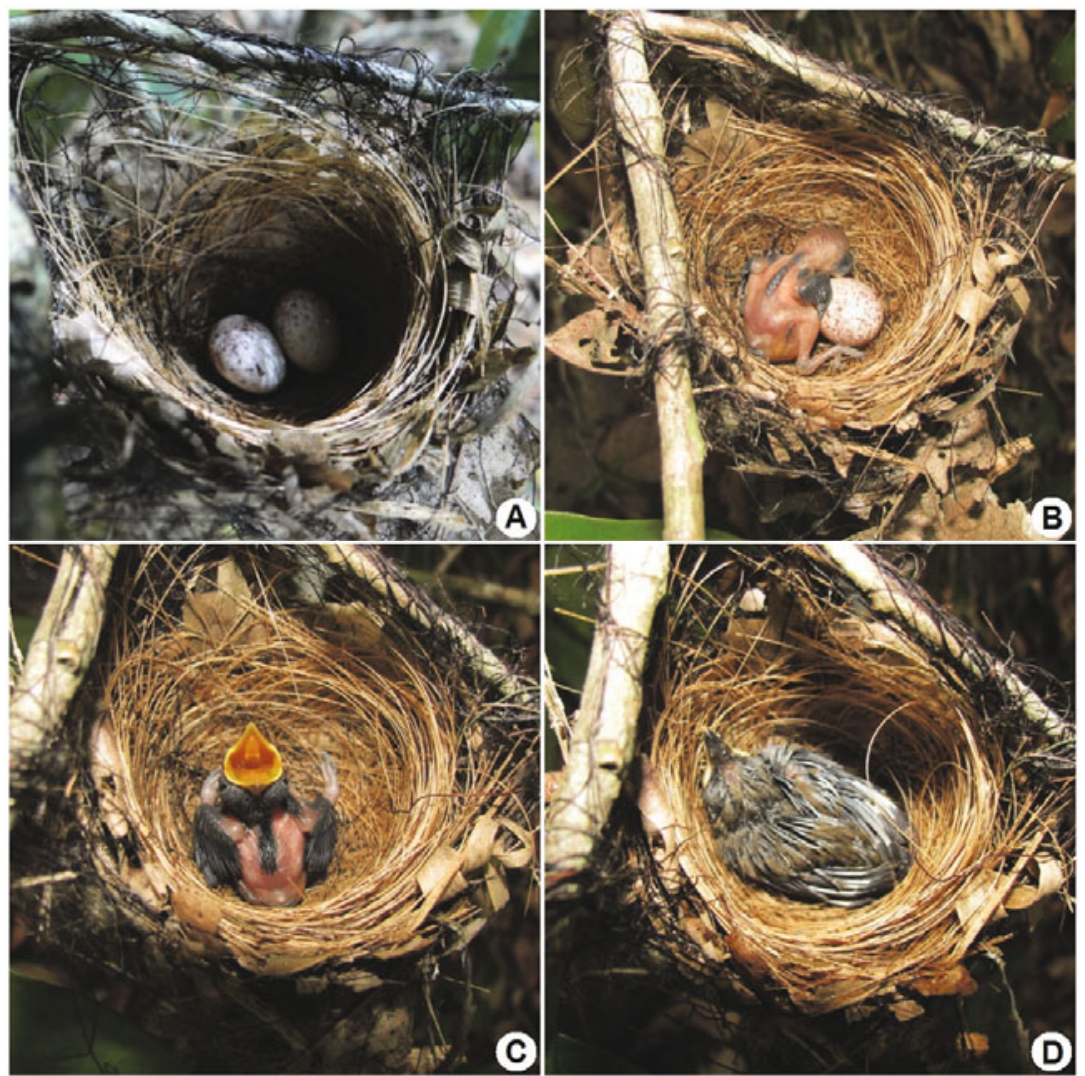

Figure 1. Nest (A), eggs (A, B) and nestling (B, C, D) of Myrmotherula luctuosa. Photo author: Cleverton da Silva. 
presence of black feather cannons, mainly on the wings, back and head (Fig. 1C). The presence of the first feathers was recorded on 18 May 2017. On that day, the nestling measured $7.2 \mathrm{~cm}$, weighed $7.2 \mathrm{~g}$, had greyish feet and tarsi and black beak, contrasting with the yellow labial commissure and mouth lining (Fig. 1D).

On 21 May 2017, the nestling was seen outside the nest with very short wings and tail, moving between the medium forest extract through short and weak flights. A plumage of color similar to that of the adult female was already observed.

\section{DISCUSSION}

The nest form, position and materials of the Myrmotherula species are diverse (Chaparro-Herrera \& Ruiz-Ovalle 2014), which makes comparison difficult if there are no clear descriptions (see Simon \& Pacheco 2005). The nest of $M$. luctuosa in this study is similar to that of $M$. axillaris, which is described as a deep bowl made of dried leaves and rhizomorphic black filaments on the outside and light filaments on the inside (Zimmer \& Isler 2003). Other Myrmotherula species, such as $M$. multostriata, $M$. pacifica, $M$. cherriei, M. longipennsis and $M$. unicolor, also use plant fibers, roots and dry leaves to build their nests (Zimmer \& Isler 2003, Chaparro-Herrera \& Ruiz-Ovalle 2014), being similar in shape but not in type or color of materials used if compared to the nest of M. luctuosa.

Table 1. Morphometry of the Myrmotherula luctuosa eggs found in the Serra de Itabaiana National Park, Sergipe, Brazil, on 08 May 2017.

\begin{tabular}{lcc}
\hline Characteristics & Egg $\mathbf{1}$ & Egg 2 \\
\hline Mass $(\mathrm{g})$ & 1.7 & 1.5 \\
Diameter $(\mathrm{mm})$ & 12.55 & 12.53 \\
Length $(\mathrm{mm})$ & 17.15 & 17.16 \\
\hline
\end{tabular}

The height at which the nest of $M$. luctuosa was built $(84 \mathrm{~cm})$ is similar to that found in nests of other species of the Thamnophilidae family, such as Cercomacra melanaria (98 cm; Pinho et al. 2006), Hypocnemoides maculicauda (113 cm; Evangelista 2008), Taraba major (128 cm; Lara et al. 2012) and Thamnophilus pelzelni $(102 \mathrm{~cm}$; Silva \& Carmo 2015). In addition, it was similar to the nest height of other Myrmotherula species: M. assimilis (380 $\mathrm{cm}$; Leite et al. 2016), M. surinamensis $(50-100 \mathrm{~cm}$; Chaparro-Herrera \& Ruiz-Ovalle 2014), M. multostriata (300-400 cm; Chaparro-Herrera \& Ruiz-Ovalle 2014), M. axillaris (20-400 m; Chaparro-Herrera \& RuizOvalle 2014) and M. unicolor (80-200 cm; Zimmer et al. 2019). M. brachyura, $M$. ignota, $M$. cherriei, $M$. minor, $M$. longipennis and $M$. menestrierii build nests high above the ground (more than $300 \mathrm{~cm}$ high) (Zimmer et al. 2019).

In general, the species of the Thamnophilidae present a clutch of two eggs, with rare cases of three eggs (Skutch 1996, Sick 1997, Robinson et al. 2000, Zimmer \& Isler 2003, Pinho et al. 2006, Perrella et al. 2015). Thamnophilidae species present eggs different in colors, and in the genus Myrmotherula important differences can be observed in the color patterns of their eggs (Zimmer $\&$ Isler 2003, Chaparro-Herrera \& Ruiz-Ovalle 2014). The $M$. luctuosa eggs observed in this study are similar to the color pattern found in M. axillaris eggs (Zimmer \& Isler 2003, Chaparro-Herrera \& Ruiz-Ovalle 2014).

The young fledged with 11 days, but it could have occurred early due to the manipulation to obtain its measurements. Other species of Thamnophilidae showed similar nestling periods, such as C. melanaria (10 days; Pinho et al. 2006), H. maculicauda (11 days; Evangelista 2008), Rhopias gularis (11 days; Perrella et al. 2017) and Taraba major (13 days; Lara et al. 2012).

During the reproductive activity, it was observed that both the female and the male participated in the incubation of the eggs (Fig. 2), and fed the nestling, like observed in other Thamnophilidae, such as C. melanaria

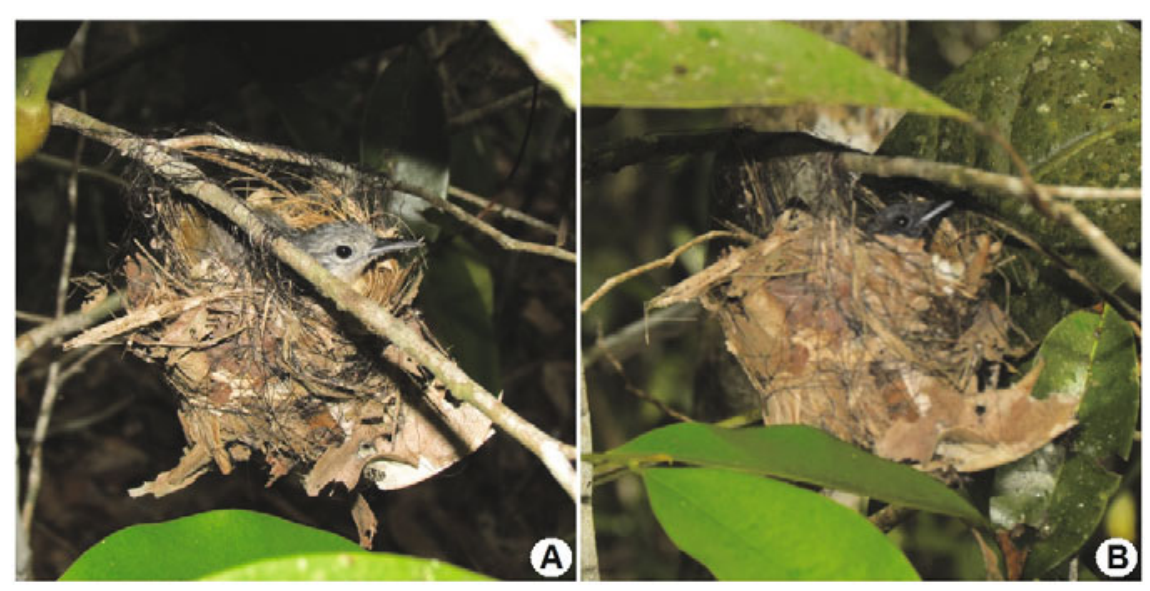

Figure 2. Female (A) and male (B) of Myrmotherula luctuosa inside the nest during the incubation and parental care periods. Photo author: Cleverton da Silva. 
(Pinho et al. 2006), H. maculicauda (Pinho et al. 2006), T. pelzelni (Silva \& Carmo 2015) and R. gularis (Perrella et al. 2017).

This is the first study to present information about the reproductive biology of the Silvery-flank Antwren $M$. luctuosa. The description of its nest, eggs and parental care add valuable information about the reproductive biology of the genus Myrmotherula, thus contributing to the understanding of the life history pattern of this group of Neotropical passerines.

\section{ACKNOWLEDGEMENTS}

Authors thank Professor Dr. Eduardo J.R. Dias, Laboratory of Biology and Ecology of Vertebrates (LABEV), Universidade Federal de Sergipe, for making available all the necessary materials for the monitoring of the nest, eggs and nestlings. Thanks also to Jefferson $\mathrm{O}$. Lima for help in the monitoring.

\section{REFERENCES}

Carvalho C.M. \& Vilar J.C. 2005. Introdução: levantamento da biota do Parque Nacional Serra de Itabaiana, p. 9-14. In: Carvalho C.M. \& Vilar J.C. (eds.). Parque Nacional Serra de Itabaiana: levantamento da biota. São Cristóvão: IBAMA.

Chaparro-Herrera S. \& Ruiz-Ovalle J.M. 2014. Anidación del Hormiguerito de Cherrie (Myrmotherula cherriei) em Colombia, com una revisión de los nidos y huevos en Myrmotherula. Ornitología Colombiana 14: 136-144.

del Hoyo J., Collar N. \& Kirwan G.M. 2019. Silvery-flanked Antwren (Myrmotherula luctuosa). In: del Hoyo J., Elliott A., Sargatal J., Christie D.A. \& de Juana E. (eds.). Handbook of the birds of the world alive. Barcelona: Lynx Editions. https://www.hbw.com/ node/1343585 (Access on 08 March 2019).

Evangelista M.M. 2008. Biologia reprodutiva, área de vida e uso de habitat de Hypocnemoides maculicauda (Pelzeln, 1868) (Passeriformes, Thamnophilidae) na região do Pirizal-Pantanal de Poconé, MT. MSc. Dissertation: Universidade Federal do Mato Grosso.
Grantsau R.K.H. 2010. Guia completo para a identificação das aves do Brasil. São Carlos: Editora Vento Verde.

Lara K.M., Pinho J.B. \& Silveira R.M.L. 2012. Biologia reprodutiva de Taraba major (Aves, Thamnophilidae) na região do Pirizal, porção norte do Pantanal, Mato Grosso, Brasil. Papéis Avulsos de Zoologia 52: 349-359.

Leite G.A., Barreiros M.H.M., Farias I.P. \& Peres C.A. 2016. Description of the nest two Thamnophilidae species in Brazilian Amazon. Revista Brasileira de Ornitologia 24: 83-85.

Perrella D.F., Biagoloni-Jr. C.H., Ribeiro-Silva L., Zima P.V.Q., Galetti P.M. \& Francisco M.R. 2015. Nest, eggs and nestlings of the Atlantic Forest endemic Star-throated Antwren (Rhopias gularis). Wilson Journal of Ornithology 127: 319-323.

Perrella D.F., Biagoloni-Junior C.H., Ribeiro-Silva L., Zima P.V.Q. \& Francisco M.R. 2017. Reproduction of the Atlantic Forest endemic Star-throated Antwren, Rhopias gularis (Aves: Thamnophilidae). Brazilian Journal of Biology 77: 356-360.

Pinho J.B., Lopes L.E., Morais D.H. \& Fernandes A.M. 2006. Life history of the Mato Grosso Antbird Cercomacra melanaria in the Brazilian Pantanal. Ibis 148: 321-329.

Robinson T.R., Robinson W.D. \& Edwards E.C. 2000. Breeding ecology and nest site selection of Songs Wrens in central Panama. Auk 117: 345-354.

Sick H. 1997. Ornitologia brasileira. Rio de Janeiro: Editora Nova Fronteira.

Silva C. \& Carmo R.S. 2015. Descrição do ninho, ovo e ninhego da Choca-do-planalto Thamnophilus pelzelni Hellmayr, 1924 (Passeriformes: Thamnophilidae) no Parque Nacional Serra de Itabaiana, Sergipe, Brasil. Atualidades Ornitológicas 185: 4-6.

Simon J.E. \& Pacheco S. 2005. On the standardization of nest descriptions of Neotropical birds. Ararajuba 13: 143-154.

Skutch A.F. 1996. Antbirds and ovenbirds: their lives and homes. Austin: University of Texas Press.

Vicente A. 1999. Levantamento florístico de um fragmento florestal na Serra de Itabaiana - Sergipe. MSc. Dissertation: Universidade Federal Rural de Pernambuco.

Zimmer J.K. \& Isler M.L. 2003. Family Thamnophilidae (typical antbirds), p. 448-681. In: del Hoyo J., Elliot A. \& Christie D.A. (eds.). Handbook of the birds of the world, $v .8$ (broadbills to tapaculos). Barcelona: Lynx Editions.

Zimmer K., Isler M.L. \& Kirwan G.M. 2019. White-flanked Antwren (Myrmotherula axillaris). In: del Hoyo J., Elliott A., Sargatal J., Christie D.A. \& de Juana E. (eds.). Handbook of the birds of the world alive. Barcelona: Lynx Editions. https://www.hbw.com/ node/56729 (Access on 08 March 2019).

Associate Editor: Caio G. Machado. 